\title{
RESILIENSI PENYANDANG TUNA DAKSA: PENGARUH DUKUNGAN SOSIAL DAN GRATITUDE DALAM MEMBENTUK INDIVIDU YANG RESILIEN
}

\author{
Fristy Vidya Kusuma Ayudia \\ Solicha \\ UIN Syarif Hidayatullah Jakarta \\ solicha.psi2011@gmail.com
}

\begin{abstract}
This study examined the relation between social support and gratitude to resilience among physically disabled. Measures of social support, gratitude, and resilience were administered on 110 adults with physically disabled randomly selected from Jakarta. Researcher hypothesized that aspects of social support (emotional support, informational support, tangible support, positive social interaction, affectionate support) and gratitude (simple appreciation, sense of abundance, appreciation for others) would be affected to resilience. Data were analyzed using Multiple Regression Analysis. The result revealed that social support and gratitude positively affected to resilience. Specifically, emotional support (aspect of social support) and sense of abundance (aspect of gratitude) contributed to higher levels of resilience. The implications of the findings in terms of providing interventions for increasing levels of resilience among adults with physically disabled were discussed.
\end{abstract}

Keywords: Resilience, Social Support, Gratitude, Physically Disabled

\begin{abstract}
Abstrak
Studi ini ingin menguji hubungan antara dukungan social dan rasa terima kasih terhadap resiliensi di kalangan orang-orang dengan disabilitas fisik. Pengukuran dukungan sosial, rasa terima kasih, dan resiliensi dilakukan pada 110 orang dewasa dengan disabilitas fisik di beberapa tempat di Jakarta. Peneliti berhipotesis bahwa aspek dari dukungan sosial dan rasa terima kasih akan mempengaruhi resiliensi. Data dianalisis dengan menggunakan analisis multiple regresi. Hasil menunjukkan bahwa dukungan sosial dan rasa terima kasih memberikan pengaruh positif terhadap resiliensi. Secara spesifik kontribusi terbesar diberikan oleh dukungan emosional dan rasa berlimpah. Implikasi dari temuan penelitian ini dalam menyediakan sebuah intervensi untuk meningkatkan tingkat resiliensi diantara orang dewasa yang memiliki keterbatasan fisik kembali di diskusikan.
\end{abstract}

Keywords: Resiliensi, Dukungan Sosial, Rasa Terima Kasih, Keterbatasan Fisik

Diterima: 12 Juni 2014

Direvisi: 17 Juli 2014

Disetujui: 25 Juli 2014 


\section{PENDAHULUAN}

Resiliensi termasuk kemampuan internal individu yang baru disadari para peneliti dan pada akhirnya mulai berkembang pada tahun 1970-an. Definisi dari resiliensi sendiri adalah hasil dari keberhasilan adaptasi terhadap situasi yang menyulitkan (adversity). Ide mengenai resiliensi adalah bahwa orangorang dapat bangkit kembali dari pengalaman hidup yang negatif dan bahkan sering menjadi lebih kuat selama proses coping, muncul dalam penelitian tentang ini (Henderson \& Milstein, 2003). Individu yang resilien tampak memiliki kebijakan khusus tentang kehidupan, jauh dari pandangan sinis tentang kehidupan (Davis \& Asliturk, 2011).

Dalam keberhasilan individu untuk menjadi resilien, hadir dua konsep yang disebut risk factors dan protective factors. Risk factors merupakan bahaya biologis, lingkungan, dan psikologis yang meningkatkan kemungkinan terjadinya dampak maladaptif (Werner dalam Murray, 2003). Sebaliknya, protective factors menjadi sumber-sumber, sebagai upaya modifikasi terhadap dampak paparan pengalaman berisiko dan mengubah kondisi tersebut (Werner \& Smith dalam Murray, 2003). Pentingnya protective factors menjadi acuan bagi peneliti untuk mengetahui pengaruh dari komponen-komponen protective factors terhadap keberhasilan individu untuk menjadi resilien. Tinjauan yang mengaitkan resiliensi dengan komponenkomponen protective factors telah banyak dilakukan, seperti penelitian terhadap coping (Dumont \& Provost, 1999; Heiman, 2002), dukungan sosial (Dumont \& Provost, 1999; Heiman, 2002; Mummery, Schofield \& Perry, 2004), emosi positif (Tugade \& Fredrickson, 2004; Tugade, Fredrickson \& Barrett, 2004; Ong, Bergeman, Bisconti \& Wallace, 2006), future expectations (Heiman, 2002), optimism (Heiman, 2002), self concept (Mummery, Schofield $\&$ Perry, 2004), self esteem (Dumont \& Provost, 1999).

Penelitian ini mencoba mengaitkan dan melihat pengaruh antara dukungan social, gratitude terhadap resiliensi dan. Dukungan sosial biasanya didefinisikan sebagai keberadaan atau kehadiran orang-orang yang kita dapat kita andalkan, orang-orang yang membiarkan kita tahu bahwa mereka peduli, menilai, dan menyayangi kita (I.G. Sarason, Levine, Basham \& B.R. Sarason, 1983). Di samping ingin mengetahui pengaruh dukungan sosial, penelitian kali ini juga akan melihat kemungkinan adanya pengaruh gratitude (bersyukur) terhadap resiliensi. Gratitude adalah salah satu bentuk dari emosi positif. Adanya emosi positif ini juga penting dalam memprediksi kemampuan individu untuk menjadi pribadi yang resilien dalam melampaui kondisi yang penuh tekanan (Tugade \& Fredrickson, 2004; Tugade, Fredrickson \& Barrett, 2004; Ong, Bergeman, Bisconti \& Wallace, 2006). Penelitian yang mendukung bersyukur sebagai bentuk emosi positif salah satunya dilakukan oleh Lambert dan rekan-rekannya. Penelitian tersebut dilakukan pada mahasiswa (17-29 tahun) dengan beban perkuliahan yang tinggi. Dalam penelitian tersebut, bersyukur dikaitkan 
dengan gejala-gejala depresi yang dialami mahasiswi. Hasil menunjukkan bahwa peningkatan frekuensi bersyukur dari waktu ke waktu meningkatkan (mencegah penurunan) emosi positif dan mencegah peningkatan gejalagejala depresi (Lambert, Fincham \& Stillman, 2011).

Pertanyaan yang kemudian muncul adalah apakah kedua faktor tersebut (dukungan sosial dan bersyukur) juga menunjukkan pengaruhnya terhadap resiliensi penyandang tuna daksa?

Penguatan atas fenomena ini datang dari penelitian terhadap orangorang dengan spinal cord injury (SCI). Secara umum, tingkat dukungan sosial yang kecil berkaitan dengan individu yang suka menyalahkan dirinya sendiri atas sakit yang dideritanya (Wilson, 2007). Ini berarti kemampuannya dalam mengatasi situasi yang sulit kurang dapat tercapai akibat kurangnya dukungan sosial yang didapat. Sementara itu, pada penyandang tuna daksa lainnya, hasil regresi menunjukkan tidak ada hubungan yang signifikan antara tingkat keparahan disabilitas dan tipe-tipe dukungan sosial (Forouzan, A. Mahmoodi, Shushtari, Salimi, Sajjadi, \& Z. Mahmoodi, 2013). Adanya hasil yang tidak konsisten ini menjadi penguat alasan bagi peneliti untuk melakukan penelitian terhadap kaitan dukungan sosial dan resiliensi secara lebih lanjut. Di sisi lain, meskipun sudah terdapat bukti nyata tentang pentingnya gratitude pada penyandang tuna daksa, namun di ranah penelitian hal ini belum banyak diungkap. Oleh karenanya, penting juga untuk mengetahui pengaruh gratitude tersebut.

\section{Resiliensi}

Resiliensi bermula dari bahasa Latin, 'resilire' (melompat kembali). Resiliensi merupakan proses mengatur sumber-sumber stres atau trauma, mengaturnya atau mengatasi secara efektif. Modal dan sumber di dalam individu, kehidupan dan lingkungan memfasilitasi kapasitas beradaptasi dan =bangkit kembali (bouncing back) 'tersebut (Windle, 2011). Resiliensi ditinjau dari segi hasil memiliki makna pemeliharaan fungsi atau perkembangan secara normal meskipun terpapar stres serius atau trauma yang meningkatkan risiko maladaptasi atau gangguan mental (Luthar, Cicchetti, \& Becker dalam Friborg, Hjemdal, Martinussen \& Rosenvinge, 2009). Sedangkan dipandang dari segi proses, resiliensi berarti seluruh faktor dan mekanisme yang mempelopori dan membentuk coping yang berguna serta keberhasilan adaptasi (Friborg, et al., 2009).

Enam faktor resiliensi berbeda yang dapat meningkatkan kemungkinan hasil yang baik, yakni (a) empat aspek yang mengindikasikan sumber-sumber intrapersonal dalam bentuk positive perception of self (persepsi diri yang positif), positive beliefs and perception of future (persepsi terhadap masa depan dan kepercayaan yang positif), warmth and social competence (kompetensi sosial dan kehangatan), dan a structured style in approaching tasks (gaya terstruktur dalam penyelesaian tugas), dan (b) dua aspek yang mengindikasikan sumber-sumber interpersonal melalui availability of family 
support and cohesion (keterpaduan dan kehadiran dukungan keluarga), serta social support and reinforcement from friends and family members (penguatan dari anggota keluarga dan teman-teman serta dukungan sosial) (Friborg, et al., 2009).

Penelitian kali ini lebih menekankan pada pengertian bahwa resiliensi merupakan suatu proses pembentukan coping yang berguna serta kemampuan beradaptasi, dimana hal ini juga turut dikemukakan oleh Friborg dkk. (2009). Selanjutnya, peneliti juga menilai bahwa dari dua aspek sumber utama resiliensi (aspek intrapersonal dan interpersonal), aspek intrapersonal dianggap dapat menjadi sumber-sumber yang menggambarkan resiliensi seseorang. Aspek intrapersonal tersebut terdiri dari positive perception of self (persepsi diri yang positif), positive beliefs and perception of future (persepsi terhadap masa depan dan kepercayaan yang positif), warmth and social competence (kompetensi sosial dan kehangatan), dan a structured style in approaching tasks (gaya terstruktur dalam penyelesaian tugas) (Friborg, et al., 2009).

\section{Dukungan Sosial}

Dukungan sosial didefinisikan sebagai informasi dari orang lain yang dicintai dan diperdulikan, dihormati dan dihargai, dan bagian dari jaringan komunikasi serta kewajiban bersama dari orang tua, pasangan atau orang yang mencintai, kerabat lainnya, teman-teman, kontak sosial dan komunitas (Rietschlin dalam Taylor, 2003), atau bahkan hewan peliharaan tertentu (J.M. Siegel dalam Taylor, 2003). Orang-orang dengan tingkat dukungan sosial yang tinggi bisa jadi kurang mengalami stress ketika menghadapi pengalaman yang penuh tekanan, dan dapat mengatasinya dengan lebih berhasil (Taylor, 2003).

Dukungan sosial yang dikemukakan Sarafino dan Smith (2011) bermakna tindakan yang secara nyata ditunjukkan oleh orang lain atau disebut dengan received support (dukungan yang diterima). Di samping itu, dukungan sosial juga berarti suatu pengertian atau persepsi bahwa kenyamanan, kepedulian dan pertolongan ada jika diperlukan-yakni perceived support (dukungan yang dirasakan). Sementara itu, Sherbourne dan Stewart (1991) melihat bahwa ketersediaan dukungan berfokus pada tersedianya dukungan fungsional saat diperlukan. Bagi mereka, persepsi seseorang tentang ketersediaan dukungan merupakan hal yang penting.

Dukungan sosial dideskripsikan sebagai faktor penting dalam beberapa domain resiliensi. Definisi singkatnya mencakup kuantitas objektif dari sumber-sumber sosial maupun proses memelihara hubungan. Dukungan sosial merupakan transaksi antara individu dan lingkungannya. Oleh karena itu, definisi dukungan sosial bukan hanya menyangkut jumlah atau fungsi hubungan sosial tapi juga meliputi persepsi terhadap dukungan (Feder, Westphal, \& Charney, 2010). Armstrong, dalam penelitiannya mengemukakan bahwa, dukungan sosial berfungsi sebagai stress mediator 
yang membuat individu menjadi lebih resisten terhadap dampak buruk stress (Armstrong, Birnie-Lefcovitch \& Ungar, 2005). Berdasarkan hasilhasil penelitian yang ada, dukungan sosial merupakan salah satu komponen dalam faktor pelindung (Henderson \& Milstein, 2003).

Berbagai pemaknaan yang diungkapkan para tokoh dan penelitian di atas, membawa peneliti pada kesimpulan bahwa dukungan sosial adalah dukungan fungsional yang diberikan orang lain (sumber-sumber dukungan) kepada seseorang yang berada dalam situasi yang menyebabkan tekanan, saat diperlukan. Kesimpulan ini juga sesuai dengan pengertian yang dikemukakan Sherbourne dan Stewart (1991).

Kaitan dukungan sosial dan resiliensi nampak dari penelitian terhadap ibu yang merawat anak dengan kondisi fisik kronis (cerebral palsy dan spinal bifida), persepsi ibu terhadap sejumlah orang yang ada untuknya maupun kepuasannya terhadap keberadaan dukungan sosial, akan berhubungan negatif dengan faktor penyebab stres (Horton \& Wallander, 2001). Ini artinya dukungan sosial mampu memberikan kontribusi positif terhadap resiliensi individu. Suatu penelitian menyatakan bahwa dukungan sosial memperkecil perilaku yang berisiko, mendorong penanggulangan aktif, menurunkan kesendirian, meningkatkan perasaan harga diri dan resiliensi serta membantu seseorang menempatkan masalah dalam perspektif tertentu (Haglund, Cooper, Southwick \& Charney, 2007).

Sherbourne dan Stewart (1991) membuat daftar bentuk-bentuk dukungan sosial yang berupa dukungan fungsional ke dalam lima bentuk:

(a) dukungan emosional, dapat diberikan melalui pengekspresian perasaan positif, memahami secara empati, dan dorongan pengekspresian perasaan;

(b) dukungan informasi, seseorang dikatakan memberikan dukungan informasi ketika dirinya menawarkan nasihat, informasi, panduan, atau feedback; (c) dukungan nyata, tercermin dari adanya pemberian bantuan secara materiil atau bantuan berupa perilaku/tindakan; (d) dukungan kasih sayang, mencakup ekspresi cinta dan kasih sayang; dan (e) interaksi sosial yang positif, yakni keberadaan orang lain untuk melakukan hal-hal menyenangkan bersama-sama. Bentuk-bentuk dukungan sosial inilah yang mampu berperan sebagai faktor pelindung dalam rangka tercapainya individu yang resilien.

\section{Gratitude}

Kata gratitude (syukur) berasal dari bahasa Latin, gratia, yang berarti anugerah, kemurahan hati, atau bersyukur. Gratitude dikonsepkan sebagai emosi, sikap, kebaikan moral, kebiasaan, trait kepribadian, dan respon coping (Pruyser dalam Emmons, McCullough \& Tsang, 2004). Gratitude merupakan suatu emosi yang muncul dari beragam sumber, mencakup (a) pandangan yang lebih positif dan apresiatif terhadap kehidupan, (b) bias positif dalam menafsirkan situasi sosial, (c) orientasi hidup ke arah yang positif di dunia, dan (d) aspek-aspek pada transaksi dan hubungan 
interpersonal (Wood, Maltby, Gillett, Linley \& Joseph, 2008). Definisi umum gratitude adalah perasaan yang dialami ketika beneficiary (seseorang yang mendapat bantuan) menerima keuntungan dari benefactor (seseorang yang memberi bantuan) (Lambert \& Fincham, 2011). Emmons (2004) mendefinisikan gratitude sebagai pengakuan dan apresiasi terhadap pemberian yang altruistis.ll Disposisi gratitude adalah kecenderungan umum untuk mengenali dan menanggapi peranan kebaikan orang-orang dengan emosi penuh rasa syukur ke dalam pengalaman-pengalaman positif dan hasil-hasil yang diperolehnya (McCullough, Emmons \& Tsang, 2002).

Sebagai salah satu bentuk emosi, gratitude dipelajari sebagai trait afeksi, yang artinya bagaimana kecenderungan seseorang saat mengalami emosi khusus. Trait afeksi gratitude, maka, dapat dikatakan sebagai kecenderungan untuk mengalami syukur. Orang-orang yang bersyukur mungkin tidak merasakan pengalaman syukur setiap saat, tetapi kemungkinan pengalaman syukur itu datang pada situasi-situasi tertentu. Individu yang bersyukur dapat dikatakan berada pada ambang syukur terendah, sehingga trait syukur harus dipandang sebagai hubungan antara disposisi syukur dan perasaan bersyukur (Watkins, Woodward, Stone, \& Kolts, 2003). Trait syukur dapat menjadi kecenderungan untuk mengalami perasaan berterima kasih dalam mengapresiasi nikmat yang diterima (Guralnik dalam Watkins, et al., 2003). Sebagai kondisi psikologis, syukur berarti merasakan perasaan takjub, berterima kasih, dan apresiasi bagi kehidupan. Syukur dapat diekpresikan kepada orang lain, serta terhadap sumber-sumber impersonal (alam) atau bukan manusia (Tuhan, hewan) (Emmons \& Shelton, 2002). Di sisi lain, Emmons dan Crumpler (2000) berpendapat bahwa syukur ialah suatu kondisi emosional dan sikap terhadap hidup yang adalah kekuatan manusia dalam meningkatkan pribadi dan berkaitan dengan well-being.

Pada penelitian kali ini, makna syukur yang digunakan peneliti berdasar pada pemikiran yang dikemukakan oleh Watkins dkk. (2003). Mereka menyebutkan bahwa syukur merupakan kecenderungan untuk mengalami perasaan berterima kasih dalam mengapresiasi nikmat yang diterima.

Beberapa penelitian menyebutkan bahwa gratitude adalah salah satu bentuk dari emosi positif. Adanya emosi positif ini juga penting sebagai protective factor dalam memprediksi kemampuan individu untuk menjadi pribadi yang resilien dalam melampaui kondisi yang penuh tekanan (Tugade \& Fredrickson, 2004; Tugade, Fredrickson \& Barrett, 2004; Ong, Bergeman, Bisconti \& Wallace, 2006).

Watkins beserta rekan-rekannya (2003) mengungkapkan karakteristik seperti apa yang seharusnya dimiliki individu yang dapat dikatakan bersyukur. Di bawah ini diuraikan keempatnya, yakni: (a) perasaan berkecukupan (sense of abundance), artinya individu yang bersyukur tidak merasakan kehilangan dalam hidup; (b) apresiasi sosial (appreciation for 
others), seseorang yang bersyukur mengapresiasi kontribusi orang lain terhadap kesejahteraan dirinya; (c) apresiasi terhadap kesenangan sederhana (simple appreciation), orang-orang yang bersyukur dapat dikarakteristikan melalui kecenderungan dalam mengapresiasi kesenangan sederhana. Individu yang mengapresiasi kesenangan sederhana seharusnya lebih cenderung mengalami perasaan bersyukur karena dirinya mengalami keuntungan subjektif lebih sering dalam kehidupan sehari-hari; (d) ekspresi rasa syukur, individu yang bersyukur seharusnya mengakui pentingnya mengalami dan mengekspresikan rasa syukur.

Pada penyandang tuna daksa, mereka dihadapkan pada kenyataan adanya kelemahan dan keterbatasan dalam melakukan aktivitas gerak. Meskipun demikian, keberadaan dukungan sosial yang bersumber dari lingkungannya tidak dapat dipungkiri mampu membantu mereka untuk kembali bangkit, menjadi individu resilien dan melanjutkan kembali kehidupannya. Faktor yang tidak kalah penting adalah adanya suatu bentuk emosi positif yang menuntun penyandang tuna daksa untuk kembali bangkit setelah mengalami situasi stress. Bentuk emosi positif tersebut dinamakan gratitude (syukur). Penyandang tuna daksa yang memiliki tingkat syukur yang tinggi akan lebih menghargai potensi yang masih dimilikinya untuk dapat melanjutkan hidup. Mereka sebagai beneficiary juga akan lebih menghargai bantuan yang diterimanya dari benefactor.

\section{Hipotesis}

Peneliti berasumsi, bahwa:

$\mathrm{H}_{1}$ : Ada pengaruh yang signifikan antara dukungan sosial dan gratitude terhadap resiliensi pada penyandang tunadaksa.

$\mathrm{H}_{0}$ : Tidak ada pengaruh yang signifikan antara dukungan sosial dan gratitude terhadap resiliensi pada penyandang tunadaksa.

Secara lebih terperinci, peneliti mengemukakan hipotesis, yakni:

1. $\mathrm{H}_{1}$ : Ada pengaruh yang signifikan antara dukungan sosial (dukungan emosional) dikaitkan dengan resiliensi pada penyandang tunadaksa.

2. $\mathrm{H}_{1}$ : Ada pengaruh yang signifikan antara dukungan sosial (dukungan informasi) berkaitan dengan resiliensi pada penyandang tunadaksa.

3. $\mathrm{H}_{1}$ : Ada pengaruh yang signifikan antara dukungan sosial (dukungan nyata) berkaitan dengan resiliensi pada penyandang tunadaksa.

$\mathrm{H}_{0}$ : Tidak ada pengaruh yang signifikan antara dukungan sosial (dukungan nyata) yang dikaitkan dengan resiliensi pada penyandang tunadaksa.

4. $\mathrm{H}_{1}$ : Ada pengaruh yang signifikan antara dukungan sosial (interaksi sosial positif) berkaitan dengan resiliensi pada penyandang tunadaksa.

5. $\mathrm{H}_{1}$ : Ada pengaruh yang signifikan antara dukungan sosial (dukungan kasih sayang) berkaitan dengan resiliensi pada penyandang tunadaksa. 
6. $\mathrm{H}_{1}$ : Gratitude (apresiasi sederhana) memberikan pengaruh yang signifikan terhadap resiliensi pada penyandang tunadaksa.

7. $\mathrm{H}_{1}$ : Gratitude (perasaan berkecukupan) memberikan pengaruh yang signifikan terhadap resiliensi pada penyandang tunadaksa.

8. $\mathrm{H}_{1}$ : Gratitude (penghargaan terhadap orang lain) memberikan pengaruh yang signifikan terhadap resiliensi pada penyandang tunadaksa.

\section{METODE}

\section{Sampel dan Prosedur}

Seratus sepuluh penyandang tuna daksa dewasa dipilih secara random dengan teknik probability sampling, dari gabungan empat panti sosial/yayasan/pusat rehabilitasi tuna daksa di beberapa kota administrasi Provinsi DKI Jakarta. Responden melengkapi paket kuesioner yang berisi instrumen pengukuran resiliensi, dukungan sosial, dan gratitude. Sampel terdiri dari 78 pria dan 32 wanita, dengan rata-rata usia 37,76 tahun $(\mathrm{SD}=$ 9,68), dan rentang usia antara 17-62 tahun.

\section{Instrumen}

The Resilience Scale for Adults. RSA yang dikembangkan oleh Friborg dkk. (2009), terdiri dari 33 item (favorabel-unfavorabel) yang dinilai melalui 5poin skala semantik diferensial. Enam faktor yang dimiliki RSA (a. Intrapersonal: persepsi diri yang positif, persepsi terhadap masa depan dan kepercayaan yang positif, kompetensi sosial dan kehangatan, gaya terstruktur dalam penyelesaian tugas; $b$. Interpersonal: keterpaduan dan kehadiran dukungan keluarga dan penguatan dari anggota keluarga dan teman-teman serta dukungan sosial) kemudian diadaptasi dan dipilih 14 item yang mewakili empat faktor intrapersonal yang digunakan dalam penelitian. Melalui adaptasi ini, maka peneliti menyebut instrumen pengukuran resiliensi menjadi The Resilience Scale for Adults-short form. Adaptasi terhadap bahasa yang digunakan juga dilakukan agar responden mampu memahami maksud dari tiap-tiap item.

The Medical Outcomes Study-Social Support Survey. Sherbourne dan Watkins (1991) mengembangkan MOS-SSS untuk dapat mengetahui ketersediaan dukungan fungsional yang dirasakan berdasarkan lima aspek dukungan sosial (dukungan emosional, informasi, nyata, interaksi sosial positif, dan dukungan kasih sayang). Instrumen ini terdiri dari 19 item dan dinilai berdasarkan 4-poin skala Likert, dimana poin 1 mewakili pilihan -tidak pernahll dan pilihan Ilsangat seringll diwakili oleh poin 4. Peneliti mengadaptasi bahasa yang digunakan dalam instrumen ini agar mudah dipahami oleh responden.

The Gratitude Resentment and Appreciation Test. Instrumen yang dikembangkan oleh Watkins et al. (2003) terdiri dari 44 item, namun tidak seluruhnya digunakan dalam penelitian ini dengan pertimbangan jumlah 
item yang banyak dapat memberatkan responden, terlebih akibat kekhususan yang dimilikinya. Oleh sebab itu, peneliti hanya menggunakan versi singkat dari GRAT yang terdiri dari 16 item. GRAT dalam versi singkat ini pernah juga digunakan pada peneliti terdahulu, yaitu Diessner dan Lewis (2007). Pernyataan-pernyataan dalam skala ini cenderung mengandung adanya bias budaya, maka peneliti kemudian melakukan adaptasi pada beberapa item pernyataan sehingga dirasa telah sesuai dengan budaya di Indonesia. Penilaian atas jawaban pada instrumen ini berdasarkan pada 4-poin skala Likert. Sistem yang diterapkan yakni pada item-item favorable, poin 1 mewakili pilihan - sangat tidak setujull dan pilihan Ilsangat setujull diwakili oleh poin 4. Di sisi lain, bagi item-item unfavorable, poin 1 mewakili pilihan —sangat setujull dan poin 4 mewakili pilihan — sangat tidak setuju.II

\section{Uji Validitas Konstruk}

\section{HASIL}

Resiliensi. Hasil analisis CFA dengan modifikasi menunjukkan bahwa 14 item dalam instrumen RSA-short form seluruhnya dinyatakan valid. Hasil ini didasarkan pada perolehan nilai Chi-square $=88.71$, $\mathrm{df}=70, \mathrm{P}$-value $=$ 0.06496 , dan RMSEA $=0.050$. Nilai Chi-square menghasilkan P-value $>0.05$ (tidak signifikan), dimana sesuai kriteria yang telah dipaparkan menandakan model dengan satu faktor (unidimensional) dapat diterima, bahwa seluruh item mengukur satu faktor saja yaitu resiliensi.

Dukungan sosial. Hasil analisis CFA terhadap masing-masing dimensi dukungan sosial menunjukkan perolehan sebagai berikut:

1. Dukungan emosional

Melalui modifikasi, empat item yang dimiliki dimensi dukungan emosional dinyatakan valid, dengan nilai chi-square $=1 ., 4, \mathrm{df}=1, p$-value $=0,19965$, dan RMSEA $=0,077$.

2. Dukungan informasi

Empat item dukungan informasi dinyatakan valid dan menghasilkan nilai chi-square $=1,62, \mathrm{df}=2, p$-value $=0,44444$, dan $\mathrm{RMSEA}=0,000$

3. Dukungan nyata

Dari empat item dukungan nyata, 1 item dinyatakan tidak valid. Sementara itu, diketahui pula nilai chi-square $=2,19, \mathrm{df}=2, p$-value $=$ 0,33392 , dan RMSEA $=0,030$

4. Interaksi sosial positif

Empat item interaksi sosial positif dinyatakan valid dan diperoleh nilai chi-square $=2,91, \mathrm{df}=2, p$-value $=0,23332$, dan RMSEA $=0,065$.

5. Dukungan kasih sayang

Dukungan kasih sayang yang terdiri dari 3 item dinyatakan valid dan diperoleh nilai chi-square $=0,00, \mathrm{df}=0, p$-value $=1,00000$, dan RMSEA $=0,000$ 
Gratitude. Hasil analisis CFA terhadap masing-masing dimensi dukungan sosial menunjukkan perolehan sebagai berikut:

1. Simple appreciation

Melalui modifikasi, diperoleh nilai chi-square $=10,69, \mathrm{df}=8, p$-value $=$ 0,21975 , dan RMSEA $=0,056$. Sementara itu, 1 dari 6 item dinyatakan tidak valid.

2. Sense of abundance

Lima item sense of abundance dinyatakan valid dan diperoleh nilai chisquare $=2,89, \mathrm{df}=5, p$-value $=0,71672$, dan $\mathrm{RMSEA}=0,000$

3. Appreciation for others

Lima item appreciation for others dinyatakan valid dan menghasilkan nilai chi-square $=8,06, \mathrm{df}=5, p$-value $=0,15308$, dan $\mathrm{RMSEA}=0,075$

\section{Uji Hipotesis}

Pengujian hipotesis dengan teknik multiple regression menunjukkan hasil bahwa $26,5 \%$ proporsi varian resiliensi diwakili oleh variabel dukungan sosial dan gratitude, sedangkan $73,5 \%$ lainnya diwakili oleh variabel lain di luar dua IV yang digunakan dalam penelitian ini. Sementara itu, tabel berikut memberikan penjelasan ada pengaruh dukungan sosial dan gratitude terhadap resiliensi pada penyandang tuna daksa. Hasil ini dapat dilihat dari nilai signifikan yang diperoleh berdasarkan uji F. Kesimpulan yang dapat ditarik, kemudian, hipotesis nihil $\left(\mathrm{H}_{0}\right)$ yang menyatakan tidak ada pengaruh dukungan sosial dan gratitude terhadap resiliensi pada penyandang tuna daksa dapat ditolak.

\section{Tabel 1}

ANOVA

\begin{tabular}{lrrrrr}
\hline Model & Sum of Squares & \multicolumn{1}{c}{ Df } & Mean Square & F & Sig. \\
\hline 1 Regression & 2891.216 & 8 & 361.402 & 4.558 & $.000^{\mathrm{a}}$ \\
Residual & 8008.784 & 101 & 79.295 & & \\
Total & 10900.000 & 109 & & & \\
\hline
\end{tabular}

a. Predictors: (Constant), Others, Nyata, Emosional, Abundance, Simple, Informasi, Interaksi, Kasih

Dependent Variable: Resiliensi

Untuk menguji apakah ada pengaruh dari masing-masing dimensi dalam dukungan sosial dan gratitude terhadap resiliensi, dilakukan uji t yang hasilnya sebagai berikut: 
Tabel 2

Koefisien Regresi

\begin{tabular}{lcccccc}
\hline Model & \multicolumn{2}{c}{$\begin{array}{c}\text { Unstandardized } \\
\text { Coefficients }\end{array}$} & $\begin{array}{c}\text { Standardized } \\
\text { Coefficients }\end{array}$ & & \\
\cline { 2 - 4 } & $\mathbf{B}$ & Std. Error & Beta & T & Sig. \\
\hline 1 (Constant) & 17.482 & 7.335 & & 2.383 & .019 \\
Emosional & .287 & .111 & .287 & 2.573 & .012 \\
Informasi & .065 & .107 & .065 & .612 & .542 \\
Nyata & -.119 & .096 & -.119 & -1.232 & .221 \\
Interaksi & -.146 & .122 & -.146 & -1.203 & .232 \\
Kasih & -.002 & .122 & -.002 & -.016 & .987 \\
Simple & .018 & .102 & .018 & .180 & .858 \\
Abundance & .446 & .093 & .446 & 4.799 & .000 \\
Others & .101 & .102 & .101 & .986 & .326 \\
\hline
\end{tabular}

a. Dependent Variable: Resiliensi

Setelah diketahui bahwa resiliensi turut dipengaruhi secara signifikan oleh dukungan sosial dan gratitude, secara spesifik, melalui uji t diketahui dimensi dari kedua variabel independen turut memberikan pengaruh signifikan terhadap resiliensi. Berdasarkan tabel 2, dimensi tersebut diwakili oleh dukungan emosional dan sense of abundance, sedangkan persamaan regresinya dirumuskan sebagai berikut. (* signifikan)

\section{Resiliensi $=17.482+0.287$ emosional $^{*}+0.065$ informasi -0.119 nyata - 0.146interaksi -0.002 kasih +0.018 simple + 0.446abundance* + 0.1010thers}

Kesimpulan yang dapat ditarik, maka, di antara delapan hipotesis minor yang diajukan, hanya dua hipotesis minor yang diterima, yaitu:

1. $\mathrm{H}_{1}$ : Ada pengaruh yang signifikan antara dukungan sosial (dukungan emosional) dikaitkan dengan resiliensi pada penyandang tunadaksa.

2. $\mathrm{H}_{1}$ : Ada pengaruh yang signifikan antara gratitude (sense of abundance) yang dikaitkan dengan resiliensi pada penyandang tunadaksa.

\section{Proporsi Varians Resiliensi}

Proporsi varians diasumsikan sebagai sumbangan atau pengaruh dari masing-masing IV setiap kali dimasukkan ke dalam persamaan. Pertambahan dari $\mathrm{R}^{2}$ ( $\mathrm{R}^{2}$ change) dapat diperhatikan seperti dalam tabel berikut. 


\section{Tabel 3}

Proporsi Varians Resiliensi dari Dukungan Sosial dan Gratitude

\begin{tabular}{|c|c|c|c|c|c|c|c|c|c|}
\hline \multirow[t]{2}{*}{ Model } & \multirow[b]{2}{*}{$\underline{\mathbf{R}}$} & \multirow[b]{2}{*}{$\begin{array}{c}\mathbf{R} \\
\text { Square } \\
\end{array}$} & \multirow[b]{2}{*}{$\begin{array}{l}\text { Adjusted } \\
\text { R Square }\end{array}$} & \multirow{2}{*}{$\begin{array}{c}\text { Std. } \\
\text { Error of } \\
\text { the } \\
\text { Estimate }\end{array}$} & \multicolumn{5}{|c|}{ Change Statistics } \\
\hline & & & & & $\begin{array}{c}\mathbf{R} \\
\text { Square } \\
\text { Change }\end{array}$ & $\begin{array}{c}\text { F } \\
\text { Change }\end{array}$ & & & $\begin{array}{c}\text { Sig. F } \\
\text { Change }\end{array}$ \\
\hline 1 & $.265^{\mathrm{a}}$ & .070 & .026 & 9.87063 & .070 & 1.575 & 5 & 104 & .174 \\
\hline 2 & $.515^{\mathrm{b}}$ & 265 & .207 & 8.90477 & .195 & 8.928 & 3 & 101 & .000 \\
\hline
\end{tabular}

a. Predictors: (Constant), Kasih, Nyata, Emosional, Informasi, Interaksi

b. Predictors: (Constant), Kasih, Nyata, Emosional, .Informasi, Interaksi, Others, Abundance, Simple

Tabel 3 di atas menunjukkan besarnya proporsi varians resiliensi yang disumbang dari tiap variabel independen. Sebesar $7 \%\left(\mathrm{R}^{2}\right.$ change $\left.=0,070\right)$ dari proporsi varians resiliensi disumbang oleh variabel dukungan sosial, sedangkan variabel gratitude berkontribusi sebesar $19,5 \%\left(\mathrm{R}^{2}\right.$ change $\left.=0,195\right)$ terhadap proporsi varians resiliensi.

\section{Tabel 4}

Proporsi Varians Resiliensi dari Masing-masing Variabel Independen

\begin{tabular}{|c|c|c|c|c|c|c|c|c|c|}
\hline \multirow[t]{2}{*}{ Model } & \multirow[t]{2}{*}{$\mathbf{R}$} & \multirow{2}{*}{$\begin{array}{c}\mathbf{R} \\
\text { Square }\end{array}$} & \multirow{2}{*}{$\begin{array}{l}\text { Adjusted } \\
\text { R Square }\end{array}$} & \multirow{2}{*}{$\begin{array}{c}\text { Std. } \\
\text { Error of } \\
\text { the } \\
\text { Estimate }\end{array}$} & \multicolumn{5}{|c|}{ Change Statistics } \\
\hline & & & & & $\begin{array}{c}\mathbf{R} \\
\text { Square } \\
\text { Change }\end{array}$ & $\begin{array}{c}\mathrm{F} \\
\text { Change }\end{array}$ & df1 & Df2 & $\begin{array}{c}\text { Sig. F } \\
\text { Change }\end{array}$ \\
\hline 1 & $.254^{\mathrm{a}}$ & .065 & .056 & 9.71609 & .065 & 7.463 & 1 & 108 & .007 \\
\hline 2 & $.261^{\mathrm{b}}$ & .068 & .051 & 9.74374 & .003 & .388 & 1 & 107 & .535 \\
\hline 3 & $.261^{\mathrm{c}}$ & .068 & .042 & 9.78825 & .000 & .029 & 1 & 106 & .865 \\
\hline 4 & $.262^{\mathrm{d}}$ & .069 & .033 & 9.83206 & .001 & .057 & 1 & 105 & .811 \\
\hline 5 & $.265^{\mathrm{e}}$ & .070 & .026 & 9.87063 & .002 & .181 & 1 & 104 & .671 \\
\hline 6 & $.274^{\mathrm{f}}$ & .075 & .021 & 9.89437 & .005 & .502 & 1 & 103 & .480 \\
\hline 7 & $.508^{\mathrm{g}}$ & .258 & .207 & 8.90356 & .183 & 25.200 & 1 & 102 & .000 \\
\hline 8 & $.515^{\mathrm{h}}$ & .265 & 207 & 8.90477 & .007 & .972 & 1 & 101 & .326 \\
\hline
\end{tabular}

a. Predictors: (Constant), Emosional

b. Predictors: (Constant), Emosional, Informasi

c. Predictors: (Constant), Emosional, Informasi, Nyata

d. Predictors: (Constant), Emosional, Informasi, Nyata, Interaksi

e. Predictors: (Constant), Emosional, Informasi, Nyata, Interaksi, Kasih

f. Predictors: (Constant), Emosional, Informasi, Nyata, Interaksi, Kasih, Simple

g. Predictors: (Constant), Emosional, Informasi, Nyata, Interaksi, Kasih, Simple, Abundance

h. Predictors: (Constant), Emosional, Informasi, Nyata, Interaksi, Kasih, Simple, Abundance, Others 
Penghitungan proporsi varians resiliensi yang disumbang oleh masing-masing dimensi dari variabel independen menunjukkan konsistensi hasil dengan pengujian hipotesis yang sebelumnya telah dipaparkan. Dukungan emosional dan sense of abundance nampak memberi sumbangan yang signifikan terhadap kemampuan beresiliensi pada penyandang tuna daksa. Hal ini dapat terlihat dari besarnya pertambahan $\mathrm{R}^{2}$ yang dihasilkan setiap kali dilakukan penambahan IV (sumbangan proporsi yang diberikan). Berdasar pada dua independen tersignifikan tersebut, dapat dilihat variabel mana yang memberikan sumbangan lebih besar terhadap variabel dependen. Caranya adalah dengan melihat $\mathrm{R}^{2}$ change, dimana semakin besar nilai dari $\mathrm{R}^{2}$ change maka akan berbanding lurus sumbangan yang diberikan terhadap variabel resiliensi. Kemudian urutan untuk kedua variabel independen dalam memberikan sumbangan dari yang terbesar hingga terkecil menjadi sense of abundance $\left(\mathrm{R}^{2}\right.$ change $=0,183$ atau 18,3\%) dan dukungan emosional $\left(\mathrm{R}^{2}\right.$ change $=0.065$ atau $\left.6,5 \%\right)$.

\section{DISKUSI}

Analisis pengaruh keseluruhan variabel independen terhadap resiliensi menyatakan adanya pengaruh dukungan sosial dan gratitude terhadap resiliensi pada penyandang tuna daksa. Pengaruh semacam ini juga dapat dilihat dari berbagai penelitian yang telah ada sebelumnya (Horton \& Wallander, 2001; Dumont \& Provost, 1999; Lambert, Fincham, \& Stillman, 2011; Tugade \& Fredrickson, 2004), yang menguji variabel dukungan sosial dan gratitude secara terpisah.

Telah disebutkan di awal bahwa pada penelitian ini, dukungan sosial memberi pengaruh yang signifikan terhadap resiliensi dan hasil ini nampak berbanding lurus dengan hasil penelitian pendahulunya (Heiman, 2002; Dumont \& Provost, 1999; Horton \& Wallander, 2001). Dukungan sosial sendiri diartikan sebagai ketersediaan dukungan fungsional yang dirasakan. Dukungan fungsional ini mengacu pada sejauh mana hubungan interpersonal mampu memberikan fungsi tertentu (Sherbourne \& Stewart, 1991). Horton dan Wallander (2001), misalnya, dalam penelitiannya pada ibu dengan anak yang mengalami cerebral palsy dan spinal bifida, menemukan bahwa persepsi ibu akan ketersediaan dukungan sosial akan berkorelasi secara negatif terhadap faktor penyebab stres. Ini artinya, dukungan sosial akan mendukung tingkat resiliensi yang lebih tinggi.

Secara lebih spesifik, dari kelima bentuk dukungan sosial yang menjadi dimensi dalam penelitian ini, hanya dukungan emosional saja yang memberikan pengaruh signifikan terhadap variabel dependen (resiliensi). Pengokohan atas hasil ini, peneliti peroleh dari sebuah penelitian yang dilakukan oleh Canadian Institute for Health Information (CIHI). Penelitian tersebut menyebutkan bahwasanya dukungan emosional nampak bertindak sebagai penyokong dalam menghadapi faktor penyebab stres (stressor) dan 
menjadi faktor protektif saat menghadapi kesulitan (CIHI, 2012). Seeman dkk., (dalam Uchino, Cacioppo, \& Kiecolt-Glaser, 1996) juga menyebutkan bahwa dukungan emosional merupakan faktor prediktor yang lebih konsisten bagi fungsi neuroendokrin, dibandingkan dengan dukungan informasi. Selain itu, pada pasien rheumatoid arthritis, ditemukan bahwa mereka yang mendapat dukungan emosional harian memiliki efek ketahanan yang lebih tinggi (Doeglas, Suurmeijer, Krol, Sanderman, van Rijswijk, \& van Leeuwen,1994). Jika ditinjau dari sumbangan terhadap proporsi varians resiliensi, dukungan emosional menampakkan hasil yang signifikan. Menurut peneliti, hasil yang demikian dapat terjadi karena melalui dukungan emosional penyandang tuna daksa dapat lebih terdorong untuk bangkit dan membangun kehidupannya dalam menghadapi situasi yang menekan (stressful life events). Berbeda halnya jika dukungan lain yang diberikan untuk mereka, yang terjadi adalah mereka akan banyak bergantung pada dukungan-dukungan yang diberikan tanpa berusaha untuk berdiri di atas kakinya sendiri.

Bertolak belakang dengan pengaruh signifikan yang dihasilkan dimensi dukungan emosional, dimensi lain dari dukungan sosial, yakni dukungan informasi, dukungan nyata, interaksi sosial yang positif, dan dukungan kasih sayang, tidak mampu memberi pengaruh signifikan terhadap resiliensi, pun dengan proporsi varians-nya. Meski dukungan informasi mampu memberi pengaruh positif, namun tidak signifikan. Sumbangan proporsi varians dukungan informasi atas resiliensi tidak pula menunjukkan hasil yang signifikan.

Terdapat beberapa kemungkinan alasan mengapa dukungan informasi tidak mampu memberikan pengaruh yang signifikan terhadap berkembangnya kemampuan individu untuk beresiliensi. Pertama, berkaitan dengan dukungan informasi, peneliti beranggapan hal ini disebabkan responden yang diteliti telah menginjak usia yang cukup matang, sehingga dalam usaha mengambil keputusan atas apa yang akan dilakukannya, mereka jarang yang meminta saran orang-orang di sekitarnya. Baik kepada keluarga, teman, ataupun kerabat lainnya. Responden juga termasuk orangorang yang mandiri dalam mencari informasi dan terkadang mereka lebih tahu apa yang sebaiknya dilakukan untuk dirinya sendiri dan orang-orang sekitarnya. Terlebih ini terjadi pada responden pria yang sebagian besar dari mereka telah berkeluarga. Berdasarkan sekilas perbincangan yang peneliti lakukan kepada responden saat mendampingi pengisian kuesioner, mereka yang tinggal di panti sosial dan yayasan ataupun pusat rehabilitasi, sebagian besar karena inisiatif mereka sendiri. Alasannya, di panti, yayasan atau pusat rehabilitasi tersebut, mereka dapat lebih berkarya dan mengembangkan diri, meski ada sebagian responden lainnya yang menetap karena terjaring razia di jalanan.

Berbeda dari kedua dukungan yang telah dipaparkan sebelumnya, dukungan nyata, interaksi sosial positif, dan dukungan kasih sayang justru 
memberi pengaruh negatif terhadap resiliensi. Hal ini dapat berarti semakin besar dukungan nyata, interaksi sosial positif, dan dukungan kasih sayang yang mereka dapatkan, maka semakin rendah kemampuan mereka untuk beresiliensi. Ini masuk akal terjadi pada penyandang tuna daksa, karena semakin banyak mereka memperoleh bantuan dari orang-orang sekitarnya, akan lebih mudah untuk mereka bergantung kepada keluarga atau kerabat mereka. Tentu ini bertolak belakang dengan konsep resiliensi, yang memiliki makna kemampuan untuk bangkit dari situasi yang menekan dan melalui mekanisme-mekanisme yang menyertainya, dapat menjalani kehidupan baru dengan kemampuan yang masih dimilikinya. Begitu pun yang terjadi jika interaksi sosial positif yang diperoleh penyandang tuna daksa tergolong tinggi, maka mereka tidak lagi memikirkan bahwa mereka harus menata kehidupannya untuk dapat beradaptasi dengan keadaannya saat ini secara lebih baik. Kondisi ini memungkinkan penyandang tuna daksa menggantungkan diri pada interaksi yang mereka jalin dengan orang lain sehingga orang lainlah yang nantinya akan membantu memenuhi kebutuhan mereka tanpa mereka harus beresiliensi. Canadian Institute for Health Information juga menyebutkan bahwa dukungan sosial yang berkaitan dengan kasih sayang, tidak menunjukkan sebagai faktor yang signifikan saat dalam situasi peralihan keluar dari tekanan psikologis (CIHI, 2012). Lagilagi ini semua berbalik kepada dukungan dasar yang lebih mereka perlukan, yakni dukungan emosional. Akan tetapi, hasil ini tidak menunjukkan pengaruh yang signifikan. Artinya, semakin tinggi penyandang tuna daksa memperoleh dukungan nyata, menjalin interaksi sosial positif, dan dukungan kasih sayang, tidak selalu akan menyebabkan rendahnya tingkat resiliensi yang dimilikinya. Ini bisa saja terjadi lantaran mereka telah cukup mandiri untuk tidak menganggap dukungan nyata, interaksi sosial positif, dan dukungan kasih sayang sebagai bentuk dukungan yang mereka perlukan. Dukungan yang memberikan mereka dorongan untuk mampu berswadaya atas diri mereka sendiri.

Selanjutnya, variabel lain dalam penelitian ini, yakni gratitude, seperti yang telah disebutkan di awal, merupakan salah satu faktor protektif yang bersumber dari dalam diri individu itu sendiri. Seperti halnya dukungan sosial, hasil penelitian juga menunjukkan adanya pengaruh yang signifikan dari variabel gratitude terhadap variabel dependen, resiliensi. Gratitude dalam psikologi positif merupakan salah satu bentuk kebaikan dari kekuatan karakter transenden, dimana hal ini berkaitan dengan keyakinan dan komitmen terhadap aspek kehidupan non-materi (universal, ideal, suci, atau ketuhanan) (Peterson \& Seligman, 2004). Oleh karena itu, gratitude dapat dikatakan secara langsung menghubungkan individu kepada kebaikan (Peterson \& Seligman, 2004). Pemaknaan gratitude dalam penelitian ini sendiri merupakan kecenderungan untuk mengalami perasaan berterima kasih dalam mengapresiasi kebaikan yang diterima (Watkins, et al., 2003). 
Sebagai salah satu ranah dalam psikologi positif, resiliensi merupakan suatu perspektif berbasis kekuatan (strength). Dengan demikian, kebaikan (virtue) dan kekuatan (strength) yang dikemukakan pada psikologi positif dapat dikatakan sebagai dasar untuk resiliensi (Chung, 2008). Penelitian yang dilakukan oleh Pentz (dalam Chung, 2008) mengungkapkan bahwa gratitude membantu orang dewasa menghadapi kanker. Chung (2008) sendiri yang melakukan pengujian terhadap kekuatan karakter apa saja yang mempengaruhi resiliensi, menyatakan bahwa secara statistik tingkat gratitude yang tinggi pada mahasiswa mampu berkontribusi terhadap tingkat resiliensi yang tinggi pula.

Lebih dalam lagi, dimensi gratitude yang secara positif signifikan terhadap resiliensi diberikan oleh sense of abundance (rasa berkecukupan). Rasa berkecukupan (atau secara negatif dinyatakan sebagai kurangnya rasa berkekurangan/lack of sense deprivation) adalah hal yang penting dalam menguatkan gratitude. Ketika seseorang merasa dalam hidupnya serba kekurangan atau jika seseorang merasa berhak mendapatkan keuntungan yang lebih dari apa yang telah diterimanya, muncul kemungkinan bahwa dirinya tidak merasakan kesyukuran. Aspek penting berkaitan dengan rasa berkecukupan adalah kemampuan mengingat manfaat yang diterima di masa lalu. Dapat disimpulkan bahwa esensi kualitas gratitude adalah kecenderungan untuk mengingat dan menikmati peristiwa kehidupan yang positif (Watkins, Grimm, \& Kolts, 2004). Dengan begitu, sense of abundance merupakan aspek terpenting dalam gratitude, sama halnya seperti yang ditampakan pada hasil penelitian kali ini.

Berkaitan dengan hasil penelitian, dimana hanya dukungan emosional dan perasaan berkecukupan saja yang menunjukkan signifikansi yang positif, hal ini kemungkinan muncul disebabkan faktor lain di luar respon sampel terhadap kuesioner. Perbedaan sampel yang digunakan memungkinan perbedaan respon yang diberikan. Pada sampel yang memiliki kecukupan dukungan sosial mungkin akan berbeda tanggapannya dibanding sampel yang sangat menginginkan mendapat dukungan sosial, namun tidak didapatnya. Begitupun dengan gratitude yang dimiliki sampel penelitian. Ketika sampel merasakan bersyukur itu penting, akan berbeda tanggapannya dengan sampel yang tidak menganggap bersyukur itu penting. Selain itu, pada instrumen, jumlah item yang diberikan dikeluhkan responden karena dapat terbilang masih cukup banyak. Oleh karena itu, hal ini dapat saja memunculkan kurang akuratnya jawaban dari responden.

Alternatif-alternatif saran dapat diterapkan mengingat munculnya keterbatasan yang berkaitan dengan hasil penelitian, antara lain:

1. Mengingat proporsi varians resiliensi yang disumbang oleh variabel dukungan sosial dan gratitude hanya sebesar $25,8 \%$, sedangkan $74,2 \%$ nya disumbang oleh variabel-variabel lain, maka penelitian berikutnya diharapkan dapat menggali lebih jauh mengenai variabel-variabel lain yang ikut berkontribusi terhadap resiliensi. Variabel-variabel lain dapat 
berupa variabel yang bertindak sebagai risk factors maupun protective factors. Faktor demografis lainnya seperti status pernikahan, status pekerjaan, atau suku bangsa dapat juga berkaitan dengan tingkat resiliensi seseorang, maka penelitian terhadap faktor demografis tersebut dapat pula didalami. Pengembangan penelitian tentang resiliensi ini juga dapat dilakukan pada kelompok-kelompok lain yang berisiko memperoleh situasi penuh tekanan, baik kelompok medis (penderita penyakit kronis, orang tua dengan anak disabilitas, korban bencana alam,dll.) maupun non medis (siswa/mahasiswa perantau, pegawai dinas sosial, jurnalis lapangan, anak korban perceraian orang tua, dll).

2. Jika peneliti berikutnya ingin melakukan penelitian lanjutan terhadap kelompok-kelompok dengan riwayat kesehatan yang rawan (penyandang disabilitas, penderita penyakit kronis, lansia, dsb.), maka peneliti perlu memikirkan jumlah item pernyataan yang akan diajukan. Sebaiknya, jumlah item pernyataan tidak terlalu banyak sehingga tidak membebani responden. Hasil jawaban yang diperoleh peneliti pun juga akan lebih maksimal. Lebih jauh lagi, responden sebaiknya diberikan pendampingan agar pemahaman yang diinginkan peneliti dan respon yang diberikan responden dapat sejalan. Selain itu, hal ini dapat menghindarkan dari kurangnya jumlah kuesioner yang disebarkan dengan yang kembali.

3. Berkaitan dengan rasa berkecukupan (sense of abundance), penting bagi penyandang tuna daksa untuk melakukan evaluasi diri harian (dapat dibantu oleh pihak panti sosial atau psikolog). Selain untuk menghitung keberkahan, evaluasi ini dapat dijadikan parameter bagi penyandang tuna daksa untuk menjalani kehidupan yang lebih baik dan lebih bermanfaat. Tidak hanya menghitung keberkahan, cerminan perasaan berkecukupan dapat ditunjukkan dengan memanfaatkan potensi diri yang masih dimiliki dan mengembangkannya menjadi suatu usaha. Dengan cara ini, diharapkan mereka dapat menjadi individu yang mandiri dan mampu mencukupi kebutuhannya sendiri.

4. Di sisi lain, meningkatkan resiliensi juga dapat diperoleh dari adanya dukungan emosional, oleh sebab itu antar warga binaan perlu saling meningkatkan komunikasi sehingga terjalin ikatan kekeluargaan yang kuat dan saling mendukung. Mereka diharapkan dapat lebih sering membagi suka duka yang dirasakannya sehingga tidak lagi merasa sendiri.

5. Demi meningkatkan resiliensi pada warga binaannya, antar panti sosial dan yayasan dapat saling mengunjungi. Dengan demikian, masingmasing individu penyandang tunadaksa dapat mengambil nilai positif dari orang lain dan hal ini dapat memacu rasa syukur pada masingmasing warga binaan. Di samping itu, antar warga binaan juga dapat saling membangun dukungan emosional. 
6. Mengingat dukungan emosional merupakan dukungan terpenting bagi terbentuknya resiliensi pada penyandang tuna daksa, maka peneliti menyarankan untuk warga binaan yang masih memiliki keluarga, alangkah baiknya jika panti sosial/yayasan mampu memfasilitasi warga binaan dan keluarganya untuk lebih dekat. Bagaimana pun, perhatian yang diberikan oleh keluarga akan jauh lebih memberikan manfaat untuk keberhasilan adaptasi penyandang tunadaksa.

7. Di setiap minggunya, panti sosial/yayasan diharapkan dapat mengadakan sesi konseling kepada psikolog bagi penyandang tuna daksa. Tujuannya ialah untuk membantu penyandang tuna daksa tersebut mengevaluasi diri atas apa kebaikan yang telah diterimanya dan patut disyukuri. Selain itu, melalui sesi konseling ini, hambatanhambatan yang masih dialami penyandang tuna daksa dapat dicarikan solusinya dan meminimalisir hambatan tersebut. Tindakan ini akan menjadi bentuk dukungan emosional yang penting bagi penyandang tuna daksa.

8. Dukungan emosional dapat diberikan melalui penyediaan psikolog untuk membantu penyandang tuna daksa saat berada di masa-masa sulitnya menerima dirinya sebagai penyandang tuna daksa. Selain itu dengan adanya psikolog, dapat membantu penyandang tuna daksa menggali kemampuan apa saja yang masih dapat dimanfaatkan dan mengoptimalkan kemampuan tersebut dalam rangka membangun kemandirian.

9. Dalam rangka membantu meningkatkan perasaan berkecukupan, yang secara otomatis berbanding lurus dengan meningkatnya resiliensi pada penyandang tuna daksa, dinas sosial dalam menyediakan fasilitas pendukung bagi penyandang tuna daksa tidak hanya diberikan di panti/yayasan atau tempat-tempat tertentu saja. Fasilitas pendukung ini mutlak diperlukan di lingkungan yang lebih luas, maka dinas sosial diharapkan dapat menjembatani penyediaan fasilitas pendukung bagi penyandang tuna daksa di setiap ruang publik. Fasilitas-fasilitas pendukung tersebut diharapkan juga tersebar merata di seluruh Indonesia. Dengan begitu, kemungkinan para penyandang tuna daksa untuk merasakan kekurangan (tidak adanya perasaan berkecukupan) akan terminimalisir.

10. Memberikan semangat bahwa anggota keluarganya masih memiliki kelebihan lain untuk dapat dikembangkan sebagai sumber daya yang dapat membantunya menjalani kehidupan yang lebih baik. Penting juga untuk menemani dan tidak meninggalkan anggota keluarganya yang menjadi penyandang tuna daksa dalam melewati masa-masa tersulitnya setelah mendapatkan musibah. Cerminan dukungan emosional lainnya yang dapat ditunjukkan kerabat penyandang tuna daksa yaitu dengan ikut membantu mengelola sumber daya dalam diri anggota keluarganya yang masih dapat dimanfaatkan untuk digunakan secara maksimal. 
11. Di sisi lain, agar penyandang tuna daksa tidak menggantungkan diri pada orang lain, keluarga harus memberikan kebebasan kepada anggota keluarganya tersebut untuk survive di lingkungan masyarakat luas. Membiarkan penyandang tuna daksa di rumah saja justru akan menimbulkan depresi tersendiri untuknya akibat perasaan tidak merasa berguna.

12. Sementara itu, dengan mengajak penyandang tuna daksa untuk melakukan kegiatan keagamaan bersama-sama, seperti beribadah bersama di tempat peribadahan sesuai agama yang dianutnya atau berdoa bersama, diharapkan dapat memunculkan rasa syukur dalam bentuk perasaan berkecukupan.

\section{DAFTAR PUSTAKA}

Armstrong, M.I., Birnie-Lefcovitch, S., \& Ungar, M.T. (2005). Pathways between social support, family well-being, quality of parenting, and child resilience: What we know. Journal of Child and Family Studies, 14(2), 269-281.doi: 10.1007/s10826-005-5054-4.

Carpenter, C. \& Readman, T. (2006). Exploring the literacy difficulties of physically disabled people. Adult Basic Education, 16(3), 131-150.

Chung, H. (2008). Resiliency and character strengths among college students. A dissertation of Educational Psychology. The University of Arizona.

Davis, C.G., \& Asliturk, E. (2011). Toward a positive psychology of coping with anticipated events. Canadian Psychology, 52(2), 101-110. doi: 10.1037/a0020177.

Dumont, M., \& Provost, M.A. (1999). Resilience in adolescent: Protective role of social support, coping strategies, self-esteem, and social activities on experience of stress and depression. Journal of Youth and Adolescence, 28(3), 343-363.

Emmons, R.A., McCullogh, M.E., \& Tsang, J. (2004). Chapter twenty one: The assessment of gratitude. Dalam Lopez, S.J. \& Snyder, C.R (ed). Positive psychological assessment: $A$ handbook of models and measures (327341). Washington, DC: American Psychological Association.

Friborg, O., Hjemdal, O., Martinussen, M., \& Rosenvinge, J.H. (2009). Empirical support for resilience as more than the counterpart and absence of vulnerability and symptoms of mental disorder. Journal of Individual Differences, 30(3), 138-151.doi: 10.1027/1614-0001.30.3.138.

Haglund, M., Cooper, N., Southwick, S., \& Charney, D. (2007). 6 keys to resilience for PTSD and everyday stress. Current Psychiatry, 6(4), 2330.

Henderson, N., \& Milstein, M.M. (2003). Resiliency in schools: Making it happen for students and educators. United States: Corwin Press, Inc. 
Lambert, N.M. \& Fincham, F.D. (2011). Expressing gratitude to a partner leads to more relationship maintenance behavior. Emotion, 11(1), 5260.doi: $10.1037 / \mathrm{a} 0021557$

Lambert, N.M, Fincham, F.D., \& Stillman, T.F. (2011). Gratitude and depressive symptoms: The role of positive reframing and positive emotion. Journal of Cognition and Emotion, 1-19.doi: 10.1080/02699931.2011.595393.

McCullough, M.E., Emmons, R.A., \& Tsang, J. (2002). The grateful disposition: A conceptual and empirical topography. Journal of Personality and Social Psychology, 82(1), 112-127.doi: 10.1037//00223514.82.1.112

transitions of youth with high-incidence disabilities. Remedial and Special Education, 24(1), 16-26.

Ong, A.D., Bergeman, C.S., Bisconti, T.L., \& Wallace, K.A. (2006). Psychological resilience, positive emotions, and successful adaptation to stress in later life. Journal of Personality and Social Psychology, 91(4), 730-749.doi: 10.1037/0022-3514.91.4.730.

Peterson, C. \& Seligman, M.E.P. (2004). Character strength and virtues: A handbook and classification. New York: Oxford University Press.

Sarafino, E.P. \& Smith, T.W. (2011). Health psychology: Biopsychosocial interactions. USA: John Wiley \& Sons, Inc.

Tugade, M.M., Fredrickson, B.L., \& Barrett, L.F. (2004). Psychological resilience and positive emotional granularity: Examining the benefits of positive emotions on coping and health. Journal of Personality, 72(6), 1161-1190.

Uchino, B.N., Cacioppo, J.T., \& Kiecolt-Galser, J.K. (1996). The relationship between social support and physiological processes: A review with emphasis on underlying mechanisms and implications for health. Psychological Bulletin, 119(3), 488-531.

Watkins, P.C., Woodward, K., Stone, T., \& Kolts, R.L. (2003). Gratitude and happiness: Development of a measure of gratitude, and relationships with subjective well-being. Social Behavior and Personality, 31(5), 431-452.

Wood, A.M., Maltby, J., Gillett, R., Linley, P.A., \& Joseph, S. (2008). The role of gratitude in development of social support, stress, and depression: Two longitudinal studies. Journal of Research in Personality, 4, 854-871.doi: $10.1016 /$ j.jrp.2007.11.0 